\title{
The Language of Appraisal in British Advertisements: The Construal of Attitudinal Judgement
}

\begin{abstract}
The article explores the occurrence and frequency of use of attitudinal judgement in British advertisement texts. Judgement, as one of the main attitudinal categories in the discourse-semantic appraisal model (Martin and White 2005), is concerned with the evaluation of human character and behaviour. The article focuses on the judgement categories of capability and propriety, as the research described concludes that they are the most frequently occurring of the judgement categories. Some typical instances encoding capability and propriety are discussed in terms of explicit and implicit manifestation. The article demonstrates that capability and propriety often participate in attitudinal double-coding due to the brevity of advertising texts and the creativity of advertising language. Capability and propriety are strongly socially motivated: they impose values upon the potential consumer, and hence upon society, and through them create social roles for the participants in the advertising interaction.
\end{abstract}

Keywords: advertisements; interpersonal meaning; appraisal; judgement; capability; propriety; attitudinal double-coding

\section{Vrednotenje $\mathbf{v}$ britanskih reklamnih oglasih: Ustvarjanje odnosa sodba}

\section{POVZETEK}

Članek obravnava pojavnost odnosa presoja ljudi in njihovih dejanj in pogostnost njene rabe v besedilih britanskih reklamnih oglasov. Presoja ljudi in njihovih dejanj, kot ena izmed glavnih kategorij odnosa v diskurzno-semantičnem modelu vrednotenja (Martin in White 2005), se nanaša na vrednotenje človekovega karakterja in obnašanja. Članek se osredotoča na kategoriji odnosa sposobnost in splošna ustreznost moralnim načelom, saj je analiza pokazala, da se ti dve kategoriji pojavljata najbolj pogosto. Obravnavani so nekateri tipični primeri, ki izražajo sposobnost in splošno ustreznost moralnim načelom eksplicitno in implicitno. Članek prikaže, da sposobnost in splošna ustreznost moralnim načelom pogosto sodelujeta $v$ dvojnem kodiranju odnosov zaradi kratke dolžine reklamnih besedil in kreativnega reklamnega jezika. Sposobnost in splošna ustreznost moralnim načelom sta močno družbeno motivirana, t.j. vsiljujeta vrednote potencialnemu potrošniku, in s tem družbi, ter ustvarjata družbene vloge za sodelujoče $\mathrm{v}$ oglaševalski interakciji.

Ključne besede: reklamni oglasi; medosebni pomen; vrednotenje; presoja ljudi in njihovih dejanj; sposobnost; splošna ustreznost moralnim načelom; dvojno kodiranje odnosov 


\section{The Language of Appraisal in British Advertisements: The Construal of Attitudinal Judgement}

\section{Introduction}

According to Brown (2001, 34), "language is a system for expression of meaning: primary function being interaction and communication". Participants enter into a relationship when they engage in communication, acting upon each other through the interpersonal meanings that they make. While the interpersonal aspect might be livelier in oral than in written communication, in print advertisements, as written forms, this aspect is much more active than one might expect. The article explores the occurrence of judgement in British advertisements, one of three main categories of attitude within the appraisal framework created by Martin and White (2005). Appraisal is an evaluative property of interpersonal meanings. The effective application of this model to various research areas, for instance, journalistic and political discourse, conversations, narratives, academic writing and e-mails (e.g., White 1998; Hood 2004; Macken-Horarik 2003; Don 2007) led to the decision to apply it to advertising texts, which are often characterised by the use of creative ${ }^{1}$ language. The subsequent results provide an insight into the frequency of the use, manifestation and social aspect of judgement values in advertisements.

Exposure to advertisements nowadays is enormous. Despite advertisers' claims that the aim of advertisements is simply to inform the public about new products, successful advertising depends on how well advertisements persuade the potential consumer to buy - using language to manipulate their emotions, behaviours, thoughts and beliefs. Advertisements tell us not only what to buy but also how to think and behave in order to 'fit into' society; in other words, how the potential consumer should satisfy the demands imposed by society upon them. Thus, in contemporary society, advertisements not only simply describe and praise the advertised product or service but they also play a crucial role in shaping and maintaining social values (Pollay and Gallagher 1990). The influence of advertisements is further reinforced by the extensive space that is reserved for advertising in many magazines (Jones 2001). I argue that the discoursesemantic appraisal model by Martin and White (2005) is a useful analytical tool for revealing how the language of advertising evaluates the participants it engages, and further, how it helps shape, reflect and naturalise values, norms and relationships through attitudinal judgement, in particular through the attitudinal judgements of capability and propriety. The existence, and hence the importance, of evaluation in all texts is clearly reflected in the following observation by Vološinov $(1973,105)$ : "No utterance can be put together without value judgement. Every utterance is above all an evaluative orientation. Therefore, each element in a living utterance not only has a meaning but also has a value."

Even though evaluation in advertising seems to be restricted to the praising of the advertised product's quality and benefits, the analysis in this article shows that judgement of human character and behaviour nevertheless occurs more often than one expects. Moreover, it contributes importantly to the relationship between the manufacturer/advertiser and the potential consumer, and hence to the persuasive rhetoric of advertising.

I use 'creative language' to mean, in particular, ellipsis, metaphors, puns, short sentences, and dispersed text/sentences around the whole advertisement. 


\section{Advertisements as Discourse}

Judgement, as an attitudinal appraisal, construes interpersonal meanings. Interpersonal function is one of three social functions performed by each clause and text (Halliday and Mathiessen 2004) and deals primarily with the relationship between the participants, i.e., their roles, and the patterns of appraisal they follow (Butt et al. 2000, 192). The notion of appraisal has evolved within the framework of systemic functional linguistics, which highlights the vital role context plays in language use, i.e., it determines the use of language in a text according to what the text aims to achieve. Givon (quoted in Leckie-Tarry 1995, 19) defines context as both "the context of culture" and "the specific context", whereby the context of culture is a "shared body of stable knowledge as coded in the lexicon carried by all members of a speech community or culture". The specific context encompasses:

a. The speaker's goals: the speech-act values (e.g., information, question, command) as well as other communicative and pragmatic goals of the speaker.

b. Interaction: the social relation between speaker and hearer, what they owe each other, what they know of each other's knowledge, goals and predispositions.

c. Discourse context: what information was processed in the preceding discourse, what can be taken for granted, what is likely to be challenged, what is important information, what foregrounds new background information and what is background (Givon, cited in Leckie-Tarry 1995, 26).

Thus, context plays a role in how language is used in a text and to what purpose. Advertising texts are no exception to this, which means that context also affects the expression of attitudes. In particular, judgement is highly sensitive to social values and norms, and is often expressed implicitly (Don 2007). Since, according to Kress $(1988,107)$, each text is written with a particular readership in mind - hence creating an 'ideal' reading position for the reader - it follows that advertisements also create an 'ideal reader' ${ }^{2}$ whom they address, i.e., for whom the text is ideally intended. For Hoey $(2001,14)$, "the audience is always a figment of the writer's imagination." Iser (cited in Selden and Widdowson 1993, 55), for example, defines an implied reader as "the reader whom the text creates for itself and amounts to 'a network of response-inviting structures' which predispose us to read in certain ways". An implied reader is thus a description of the reading position to which the actual reader is invited to conform (Macken-Horarik 2003). Moreover, according to Rimmon-Kennan $(1983,118)$, an implied reader is also defined as "an image of a certain competence brought to the text". Eco $(1979,7)$ terms the competence presupposed on the reader's part as "encyclopedic competence", which we know, while the 'real' reader cannot be known. Eco $(1979,3)$ further postulates that "the very existence of texts [...] cannot only be freely interpreted but also cooperatively generated by the addressee." Thus, the addressee also brings with him/her their knowledge and experience, which may differ from the mental images received through the ideal reading position, hence interpreting the text differently. In order to address the reader effectively, his/her reading position should conform to the ideal reading position, including the value system, beliefs, thoughts and norms established around the advertised product.

In recent literary studies, an array of terms have been used to refer to this reader, e.g., implied reader, imagined reader, ideal reader, historical reader, mock reader and informed reader. However, the division of texts into 'literary' and 'non-literary' should not be rigid (Lamb 2014, 80). The 'implied reader' is a more popular term in recent literary studies and refers more to the ideal reading position established in the text (Wales 2014, 208). In advertising, the term 'implied consumer' is also used (Stern 1994); in this study, the term 'potential consumer' is used. 
The importance of the relationship between the writer and the reader in writing and interpreting texts is also acknowledged by Hoey (2001), who says that it is the relationship between the writer and the imagined reader on which written discourse is based; within this relationship, the writer makes assumptions about the ideal reader's expectations and knowledge, and attempts to act accordingly. In advertisements, as in other texts, this is also reflected through the use of language, including attitudes. Similarly, the role of assumptions in creating a text and in using language accordingly is well explained by Kress and Hodge (1979, 5), who argue that a language is a "system of categories and rules on fundamental principles and assumptions about the world" that "are embodied in language, learnt through language, and reinforced in language in use."

As the advertisements under scrutiny occurred in magazines addressing mainly a female readership, it is expected that the actual reader is female. Some evidence for this can be found in the use of nouns women and girls, as a way of addressing the reader in some of the advertisements. The 'ideal reader' of the advertisements in this study may be recognised as someone having problems, which fits the problem-solution pattern on which most advertisements are based. The language of advertisements also fits this pattern, as do the values, norms and relationships expressed within them. Hoey (1994) categorises the problem-solution pattern into problem, solution, response, result/solution and evaluation. In advertisements, the solution to the featured problem, and response and evaluation, are typically contained in a single sentence (they overlap) in advertisements, as shown in the example below:

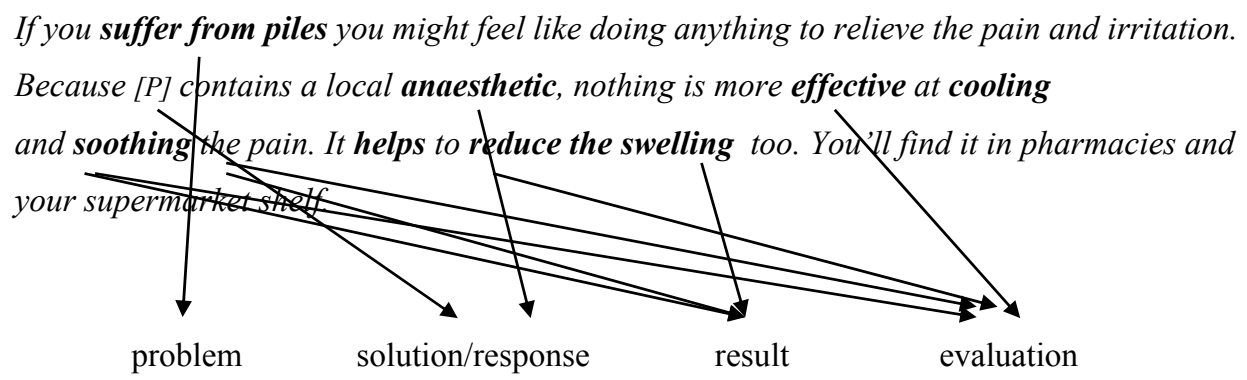

However, it is not only the writer who is active in a written text but also the reader, even though, in contrast to oral conversations, no immediate response is expected. In advertising, the careful choice of language navigates the active reader to make meanings and connections, with the ultimate goal of selling the product or service. Accordingly, predictions and assumptions are made about the potential consumer's knowledge, and the advertiser displays 'familiarity' with their lifestyle, beliefs and expectations. In this way, advertisements target the potential consumer's feelings, prescribe appropriate behaviour for them and remind them about inappropriate behaviour. Advertisements also establish roles for the participants they engage, demand that potential consumers identify with others, and at the same time, attempt to trigger reactions, and change beliefs and values. Furthermore, advertisements express various attitudes towards the products they feature as well as the potential consumer, other people, and the world.

\section{Appraisal}

According to White $(2001,1)$, appraisal is “[a] particular approach to exploring, describing and explaining the way language is used to evaluate, to adopt stances, to construct textual personas and to manage interpersonal positioning and relationships." 
The descriptive and evaluative functions of language have long been acknowledged. Richards was one of the first $(1926,267)$ to recognise that aspect as well as the evaluative function of scientific use of language. Jacobson describes the evaluative aspect as being reflected through the referential, poetic, emotive, conative, phatic, and metalinguistic functions of language (1960). Hayakawa ([1939] 1972, 38) defined evaluation in terms of judgement as "all expressions of the writer's approval or disapproval of the occurrences, persons, or objects he is describing", while Labov (1972) identified several linguistic elements as performing the evaluative function of language (e.g., intensifiers, evaluative comments, exclamations, comparisons). Subsequently, the evaluative aspect of texts has been observed, for instance, by Poynton (1985/1989), Lemke (1998), and Carter (2004).The ideological value of the evaluative was emphasised by CaldasCoulthard (1996), who through her research on women's magazines discovered that evaluation plays an important role in conveying ideological values.

Martin and White (2005) developed the appraisal model as a functional model of evaluative language at the level of discourse semantics. Discourse-semantics is the content stratum which carries the function of directly realising social context. According to Halliday and Mathiessen (2004), language is stratified, i.e., it functions on different planes of content and expression. Thus, appraisal is a discourse-semantic resource for construing interpersonal meanings which is realised by lexico-grammar. In the appraisal model, appraisal is divided into the categories of attitude, graduation and engagement; it is concerned with feelings (affect), behaviour and character (judgement), and the evaluation of things (appreciation). Graduation is concerned with the grading of attitudinal meanings, whereas engagement is concerned with adopting stances towards the value positions created in the text and by the addressees.

The category of judgement is one of the three categories of attitude and is concerned with the evaluation of human behaviour and character. At the early stage of children's language development, it is the child's own feelings and behaviour that are mainly evaluated (Painter 2003, 206). Iedema, Feez and White (1994) argue that categories of judgement are motivated primarily by the categories of modality: usuality, ability, inclination, probability and obligation. Thus, the values of capability involve either ability or disability in their semantics (e.g., the semantics of clever involves a positive assessment of ability). In the appraisal model (Martin and White 2005), judgement is divided into the categories of normality (how special one is, e.g., lucky), tenacity (how dependable one is, e.g., cautious), capability (how capable one is, e.g., clever), veracity (how honest one is, e.g., frank) and propriety (how far beyond reproach one is, e.g., kind). As with all attitudes, judgement can have a positive or negative status, and can be expressed explicitly (directly) or implicitly (indirectly) ${ }^{3}$. Explicit judgement is encoded lexically, i.e., via attitudinal lexis (e.g., brave), while implicit judgement is not encoded directly in attitudinal lexis, but is often context and co-text bound and may be evoked via an ideational meaning of an instance or its associations, or other linguistic elements. As Channel $(1999,38)$ states, covert evaluative meaning is often created on the basis of the associations words take on.

\section{Data and Methodology}

The data are gathered from the texts of 200 randomly selected British print advertisements. All of the advertisements appeared in British women's magazines, advertising primarily beauty and health products, and products for domestic use. The advertising texts included the main body

Explicit attitudes are also referred to as inscribed attitudes in literature, and implicit attitudes as tokens or evoked attitudes. 
of text, headline, slogan and logo, if given close to the main body of the text, and comprised around 15,000 words in total. The textual sections were transcribed in the form of a connected text, sinistrodextrally, from top to bottom and from left to right, and divided into sentences. In each of these sentences, the instances of explicit and implicit attitude were first identified and counted to obtain the total number of occurrences in advertisements. Then, within these attitudes, all the attitudes of judgement were identified and coded in terms of judgement subcategories, attitudinal status (positive/negative) and type of attitudinal realisation (explicit/implicit) following the Martin and White (2005) appraisal model. A coding $\operatorname{tag}^{4}$ was provided next to each identified instance of judgement in attitudes, and then these tags were counted in each advertisement to obtain the total number of occurrences. Finally, the average frequency of occurrence of judgement categories, of their status and realisation in advertisements was calculated 5 by using the arithmetic means formula to establish their patterns and preference of use. The results are presented in the following section, which is organised as follows. The frequency of occurrence of judgement categories in attitudes and of judgement categories in explicit and implicit judgement attitudes is displayed in Tables 1 and 2, respectively, alongside the interpretation of results. Then, the prevailing attitudes of judgement capability and propriety are discussed in terms of explicit and implicit manifestation, realisation and social role. The data are displayed in Tables 3 and 4, respectively, with the interpretation of results. A selection of typical examples is provided and commented on, as the number of examples exceeds the scope of this paper. Additionally, the potential of some linguistic elements to trigger the values of capability and propriety are exemplified.

\subsection{The Attitudinal Coding}

The coding decisions for each of the judgement categories were based primarily on questions provided by Martin and White $(2005,53)$, for example, how capable someone is (for capability) or how ethical someone is (for propriety), taking into account the existing values and norms of our modern (consumerist) society. In addition, examples provided by Martin and White (2005) were also useful in the coding process. For example, capability values also encompass lexis conveying semantic meanings related to knowledge, intelligence, expertise, skills (e.g., witty, clever, expert, educated); instances in advertisements sharing the same or similar semantic meanings directly or indirectly with the mentioned concepts were therefore coded as capability. Additionally, other studies on appraisal and their exemplifications were also helpful (e.g., White 1998, 2001; Hunston 1999; Don 2007, 2016; Macken-Horarik 2003; Hood 2004; Bednarek 2009; Isaac 2012). Since the coding of attitudes was often problematic due to the brevity of the language in the texts, the denotative meaning of ambiguous instances in the context of advertising was also a criterion for identifying judgement. For example, the denotative meaning of the lexical word deserve is "if you deserve something, it is right that you get it, for example because of the way you have behaved" (MacMillan English Dictionary for Advanced Learners 2007, 398). Additionally, the identification of judgement, as of any attitude, relies heavily on the co-text (the vicinity of linguistic elements in the same clause and near-by clauses, at the level of an individual advertisement) and the cultural, situational and ideological context, which makes

For example, the coding tag for the inscribed positive judgement capability was placed next to the instance conveying capability (e.g., according to the skincare experts (ins/judg: cap:+ )). The coding tag for the evoked positive judgement capability, meanwhile, was placed next to the linguistic trigger or at the end of the sentence/clause if it was evoked at the clause level (e.g., but medical research (-t/judg:cap:+) confirms $80 \%$ of cases can be cured)).

$M=\frac{\Sigma X}{n}$ 
evaluation a highly complex phenomenon (e.g., Hunston 1999, Bednarek 2009). Thus, based on the denotative meaning of deserve in the vicinity of a positive attitude (the best) in example (37), which provides no indication of why someone is deserving, we assume that appropriate female behaviour, according to societal norms, is being signalled, i.e., caring for other members of the family (via cooking). Similarly, in example (39), the recognition of the manufacturer's caring attitude in the lexical designed is further supported with the positive attitudes expressed lexically with help, protect and health, and the purpose marker to in its vicinity.

Although it is the advertised product that is evaluated as helpful, the human participation in the making of the product in order to meet the potential consumer's needs should not be ignored. Moreover, despite the product itself being the focus of attention in advertisements, it is nevertheless presented from the perspective of the writer ${ }^{6}$ of the text to trigger the buying impulse in the potential consumer. I argue that the writer's (in particular, his/her non-visible) participation in appraising cannot be entirely excluded from the analysis of attitudes. Thus, what is intended in/ with the text is also highly important. Since much of this might be implied, the analyst first has to adopt a neutral reading position, and, second, imagine the role of both the manufacturer and the potential consumer as participants, in this way opening up more interpretative possibilities. As a result, attitudes may have multiple overt or covert targets (Hunston and Thompson 1999, 177; Isaac 2002, 224). Although the complete avoidance of undesirable subjectivity in the analysis of attitudes is impossible (Martin and White 2005, 62), double/multi-coding is necessary in order to exhaust the possible multiple interpretations (Page 2003). Even though double-coding is permitted in some cases in Martin and White's (2005) appraisal model, it is not discussed sufficiently. Double-coding can mean that one lexical item encodes two or more categories (e.g., pride $=$ affect and judgement), or that the context and co-text trigger additional attitudes via one lexical item (see example (13)) or at the clause level. As Page $(2003,216)$ observes, the inscribed attitude of one lexical element may be identified as evoked elsewhere in a text, depending on the context. In recent studies on appraisal, the necessity for double/multi-coding, as reliability rater, is also discussed within the multi-layered feature of evaluation (e.g., Isaac 2012; Bednarek 2014; Thompson 2014; Macken-Horarik and Isaac 2014). A viable solution to the problem of ambiguities and reliability pertaining to attitudinal coding is also the expansion of the existing model (e.g., Bednarek 2006; Hommerberger and Don 2015). Although the analysis of appraisals is still mostly conducted manually, the necessity for higher reliability of attitudinal coding by "defining explicit annotation criteria" is emphasised by Fuoli (forthcoming, 23), but this still raises questions about maximum reliability, as the criteria have not yet been fully established.

The promising UAM corpus by O'Donnell (2008) focuses on the use of the tool rather than on the reliability factor, and is also more suited to quantitative rather than qualitative research (Macken-Horarik and Isaac 2014). The approach used to the attitudinal coding in my research (the identification of participatory linguistic elements and the description of contextual factors in the coding process) shares many similarities with the approach proposed by Don (2016), in which she provides a "more fine-grained account of how attitudinal values may be typically and potentially activated indirectly in discourse" by systematically providing an array of linguistic elements that participate in the identification of attitudes. Adopting the analytical approach explained above resulted in a substantial number of attitudes, which when taken into consideration result in an increase in the overall number of attitudes, in particular implicit examples.

Since in advertising it is difficult to determine who exactly the author of the text is (e.g., advertising agency, the manufacturer him/herself), the terms writer, author, advertiser, and manufacturer are captured in the term manufacturer in this paper, although they are occasionally used interchangeably. 


\subsection{Advertisements as Multimodal Texts}

The onslaught of multimodal texts in contemporary society has attracted the attention of researchers, who acknowledge the accomplishing function of each mode in meaning making (e.g., Kress and Van Leeuwen 1999, 2006; O' Halloran 2005; Thibault 2000; Tan 2010; Stoian 2015). Moreover, "semiotic resources perpetuate ideologies and legitimise and transmit cultural values" (Bowcher 2012, 2). According to Lemke (1998), the advantage of exploring the verbal text is seen in the ability of language to convey meanings and in its sensitivity to time, whereas visuals are more sensitive to space. Even though the print advertisements under scrutiny combine both semiotic systems, i.e., the verbal and non-verbal, the focus in the analysis was solely on the verbal elements. The reason for exploring text only is twofold: firstly, the analysis of judgement is already extremely detailed, and the visuals in advertisements would require separate detailed analysis (qualitative and quantitative) to produce a comparison-worthy set of results; secondly, since visuals are objects of visual perception (Saint-Martin 1990), the addressee may be left with various possible interpretations, while the textual element conveys clearer meanings. However, a glimpse at the visuals in advertisements shows that in many cases they do reflect the content of the text or its parts, and also mainly conform to the problem-solution pattern. While the attitudinal aspect is signalled (e.g., the value of the natural in green grass, emotions revealed through facial expressions, coloured food, flawless legs), hence yielding reinforced attitudinal meanings, it is rarely displayed as judgement. As judgement, it is expressed, for example, through the concepts of the expertise and scientific approach which have contributed to the product's development, hence encoded as capability (e.g., laboratory equipment or a needle placed next to a health product; silicone and collagen substances shown in the skin; a graph; a substance on laboratory equipment to be added to a product; ginger in an ice cube as an added ingredient; a photo of a dentist; a white coat as a symbol of medicine). Capability is also displayed as a woman's/mother's ability to handle multiple tasks and roles, reflected in six arms stretching out from a female body, each one carrying a symbol of a particular task, e.g., a football shoe, a phone, an oil pump, a book, a lipstick, and a dryer. Normality, for example, is reflected in an elegant stiletto signifying a sophisticated woman, while propriety is displayed as a mother's attitude in caring for her child's well-being by using soft towels.

\section{Analysis of Attitudinal Judgement: Capability and Propriety}

In this section, capability and propriety are analysed in terms of their frequency of occurrence, manifestation and status.

TABLE 1. Judgement categories in attitudes.

\begin{tabular}{|l|c|}
\hline $\begin{array}{l}\text { Number of all attitudinal occurrences } \\
(\mathbf{n}=\mathbf{6 1 3 8})\end{array}$ & \\
\hline normality & $42(0.68 \%)$ \\
\hline capability & $476(7.75 \%)$ \\
\hline tenacity & $42(0.68 \%)$ \\
\hline veracity & $42(0.68 \%)$ \\
\hline propriety & $300(4.88 \%)$ \\
\hline
\end{tabular}


Table 1 shows that advertisements, regarding judgement values, are characterised by an extensive range of resources of judgement capability $(7.75 \%)$ and propriety $(4.88 \%)$, whereas the resources of judgement normality, tenacity and veracity contribute the same ratio of only $0.68 \%$ of all attitudinal cases. This pattern points to the strong emphasis on the values of capability and propriety in advertisements. To compare, the research on attitudinal language in advertisements of houses made by estate agencies showed no instances of judgement (Beangstrom and Adendorff 2013, 337). The reason for the expression of judgement attitudes might depend on the type of advertisement, i.e., what is advertised. Since advertisements in my study advertise primarily beauty, health and products for domestic use, hence dealing with rather delicate topics, they attempt to establish a closer, friendly contact with the potential consumer, hence personalising the advertising voice. The results of the chi-square test $\left(x^{2}\right)$ for the judgement categories show that there is a significant difference between the observed categories $\left(x^{2}=882.16 ; \mathrm{fe}=180.4 ; p\right.$ $\left.=0.001(18.47) ; \mathrm{df}=4 ; p \leq x^{2}\right)$.

TABLE 2. Explicit and implicit realisations of judgement categories in advertisements.

\begin{tabular}{|l|c|c|c|c|c|}
\hline & norm & cap & ten & ver & prop \\
\cline { 2 - 6 } & $\exp$ & $\exp$ & $\exp$ & $\exp$ & $\exp$ \\
\hline $\begin{array}{l}\text { number of all attitudinal } \\
\text { occurrences } \\
(\mathrm{n}=6138)\end{array}$ & $\begin{array}{c}18 \\
(0.29 \%)\end{array}$ & $\begin{array}{c}147 \\
(2.40 \%)\end{array}$ & $\begin{array}{c}10 \\
(0.16 \%)\end{array}$ & $\begin{array}{c}3 \\
(0.05 \%)\end{array}$ & $\begin{array}{c}23 \\
(0.38 \%)\end{array}$ \\
\hline & $\mathrm{imp}$ & $\mathrm{imp}$ & $\mathrm{imp}$ & $\mathrm{imp}$ & $\mathrm{imp}$ \\
\hline $\begin{array}{l}\text { number of all attitudinal } \\
\text { occurrences } \\
(\mathrm{n}=6138)\end{array}$ & $\begin{array}{c}24 \\
(0.39 \%)\end{array}$ & $\begin{array}{c}329 \\
(5.35 \%)\end{array}$ & $\begin{array}{c}32 \\
(0.52 \%)\end{array}$ & $\begin{array}{c}39 \\
(0.63 \%)\end{array}$ & $\begin{array}{c}277 \\
(4.50 \%)\end{array}$ \\
\hline
\end{tabular}

norm $=$ normality $\quad$ cap $=$ capability ten $=$ tenacity $\quad$ ver $=$ veracity prop $=$ propriety $\exp =$ explicit imp = implicit

As shown in Table 2, both explicit and implicit capability are expressed much more frequently in all attitudinal cases than are other judgement attitudes, with the ratio of $(2.40 \%)$ and (5.35\%), respectively. Propriety is expressed second most frequently, with the ratio of implicit propriety $(4.50 \%)$ higher than the ratio of explicit propriety $(0.38 \%)$. The frequent expression of implicit capability and propriety values signals that advertisements are also concerned with the participants and not only with the product, which should be the centre of attention. As discussed later in the paper, implicit capability and propriety often participate in shaping the value system of the addressees as part of the persuasive strategy. Explicit and implicit normality, tenacity and veracity are expressed much less frequently. The results of the chi-square test $\left(x^{2}\right)$ for the explicit and implicit realisation of judgement categories show that there is a significant difference between the observed categories $\left(x^{2}=1.433 ; \mathrm{fe}=90.2 ; p=0.001(27.88) ; \mathrm{df}=9 ; p \leq x^{2}\right)$.

\subsection{Explicit and Implicit Capability}

Table 3 shows the pattern of judgement capability in terms of its status and manifestation in advertisements. 
TABLE 3. Status in explicit and implicit capability attitudes.

\begin{tabular}{|l|c|c|c|}
\hline $\begin{array}{l}\text { explicit capability } \\
\mathbf{n}=\mathbf{1 4 7}\end{array}$ & $\begin{array}{c}\text { implicit capability } \\
\mathbf{n}=\mathbf{3 2 9}\end{array}$ & \\
\hline positive & $128(87 \%)$ & positive & $286(87 \%)$ \\
\hline negative & $19(13 \%)$ & negative & $43(13 \%)$ \\
\hline
\end{tabular}

Table 3 reveals that both explicit and implicit capability share the same ratio of positive (87\%) and negative status (13\%). The much more frequent expression of positive capability, both in its explicit and implicit form, means that the positive value of capability is the advertisers' preferred choice. The results of the chi-squared test $\left(x^{2}\right)$ for the category judgement in Table 3 show that there is a significant difference between the observed categories $\left(x^{2}=436.5 ; \mathrm{fe}=119 ; p=0.001\right.$ (16.27), $\left.\mathrm{df}=3 ; p \leq x^{2}\right)$.

The analysis shows that explicit capability is encoded frequently in lexical instances conveying the knowledge and skills that the manufacturer has employed in the product's development, hence carrying a positive status, as in (1-6). Grammatically, these instances are realised mainly as things. The target in such cases is mainly the manufacturer, a member of a company or some reliable external source whose skill and knowledge are indicated by a professional title, or field of expertise, which intensifies the values of credibility and trust. The value of expertise is strengthened by pairing the instances which encode capability via expertise with the instances which encode capability via superiority. The pairs are usually grammatically realised as epithet/ classifier + thing (5), and their aim is obviously to render the advertised product more credible, which additionally evokes the attitude of positive appreciation targeting it. Often the expertise encapsulated by a product or brand is further emphasised via a circumstance conveying location (6), a classifier (1), and an actor in the material process (4).

(1) This is a problem that $[\underline{B}]^{7}$ skin experts say can affect our mood as well as our looks.

(2) That's why it needs [P], the brand most often recommended by healthcare professionals.

(3) 17 years of innovation and success in shave built up our scientific expertise and popularity and made us the No1 SPECIALIST BRAND IN ANTIAGEING TREATMENTS IN FRANCE.

(4) Whatever cosmetic surgery you may be considering [ $[$ ] gives you access to outstanding skills.

(5) Created and constantly monitored by the world-leading herbalist dr. [B], a cup of [P] cleans your body of impurities and is sure to get your motor running.

(6) According to the skincare experts at [B], it's a simple combination of water intake and moisturisation.

Explicit capability is further identified in the manufacturer's ability to solve the potential consumer's problem $(\mathrm{s})$, signalled via an incongruent ${ }^{8}$ realisation of capability, realised as can do (7), in what the potential consumer is able to do after using the product (8). This can also be seen

Brand names and names of products marked P (product) and B (brand) in order to avoid brand and product recognition.

According to Martin (1992, 410), experiential meanings can be realised congruently or incongruently. Incongruent realisations can be unpacked into various 'congruent' realisations. For example, capability can be unpacked into can do or making strenuous effort, or advance into make better. 
in the encouragement of a healthy lifestyle, which in this way is introduced as a positive value, as shown in (9).

(7) [B] and his highly skilled team can give you that confidence.

(8) So now, when you wear your face on heels ... you can party on ... and on ...

(9) By staying fit, eating healthily and including friendly bacteria in your daily diet, you can stack the cards against them.

Capability is further encoded directly in instances realised as catenative verbs, which target the consumer's ability to achieve the best results with the product's help, as in (10), whereby the first verb in the pair inscribes positive appreciation targeting the product. Thus, the product's benefit increases the potential consumer's ability to 'improve' hair.

(10) While thickening shampoos only make your hair look thicker, [P] gets to the root of the problem stimulating re-growth by nourishing follicles, helping thousands of women to grow thicker, lusher and stronger hair.

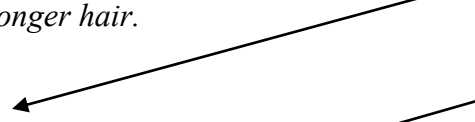

explicit positive valuation; target: the protuct's helpful performance
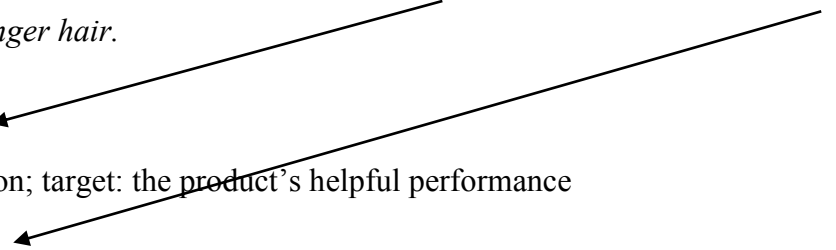

explicit positive capability; target: the potential consumer's (women) ability to grow stronger hair after the product's use

Knowledge as an indicator of capability value is further encoded directly in the instance know, which is realised as a process in a mental clause on the basis of some of its denotative meanings, such as "to have learned or found about something [...] to realize or understand something" (MacMillan English Dictionary for Advanced Learners 2007, 833). In most cases, the manufacturer possesses knowledge which they share with the potential consumer, as in (11), or even presents it as a universal truth (via the amount quantifier all) with which the potential consumer is expected to be familiar, as in (12). While the use of the exclusive pronoun we in (11) attributes the awareness of positive reaction in the potential consumer solely to the manufacturer, in (12), the use of the inclusive pronoun we paired with the amount quantify all presents the knowledge about healthy and toned skin as symbols of good looks as shared between the manufacturer and potential consumer.

(11) We know how to be pleasantly surprised with the results!

(12) We all know that healthy, toned skin, free from niggling lines and imperfections is the secret to looking our very best - whatever our age!

In some cases, sharing important information implies a lack of knowledge on the potential consumer's part, which additionally evokes negative capability. This is often paired, and of course contrasts, with the explicitly expressed capability targeting the manufacturer. Excerpt (13), in which manufacturer's knowledge about the inefficiency of ordinary conditioners is shared via a rhetorical question presupposing a negative answer, illustrates this. Rhetorical questions, which 
indirectly assume/imply a lack of knowledge on the part of the potential consumer, may be regarded as less "threatening", i.e., preserving the potential consumer's self-image in comparison to categorical assertions (e.g., you don't know that) (Brown and Levinson 1987).

(13) New [P] conditioner. Maintains the protection of your anti-dandruff shampoo. Did you

know that ordinary conditioners could simply wash away the protection you get from your anti-

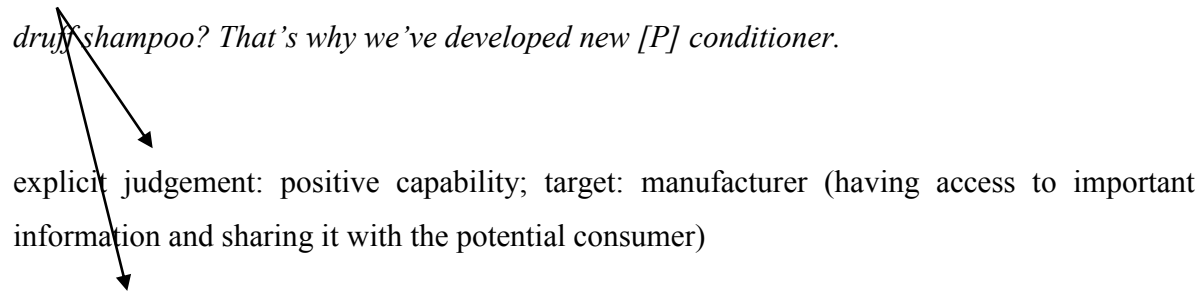

implicit judgement: negative capability (lacking knowledge about ordinary conditioners)

Another example of double-coding is presented in (14), in which the word-play observed in the instance wiser in the elliptical statement (no verb), realised grammatically with the epithet, and coupled with the instance way, which signals a solution within the context of this advertisement, allows for two interpretations: firstly, the possible semantic levelling of wise with efficient, evaluating the product positively (explicit positive appreciation); secondly, the possible equating of wisdom with the potential consumer's (pronouns you and your in the subsequent sentences in the same text) ability to make wise decisions, one of which is choosing the advertised product (explicit positive judgement). The reason behind the wise choice is expressed via the many positive direct and indirect evaluations of the advertised product in the subsequent sentences in the same text (help, more calcium, balanced diet, shape, efficiently, manage weight). Additionally, way signals a solution, hence inscribing positive appreciation targeting the product.

explicit positive appreciation targeting explicit positive appreciation targeting the

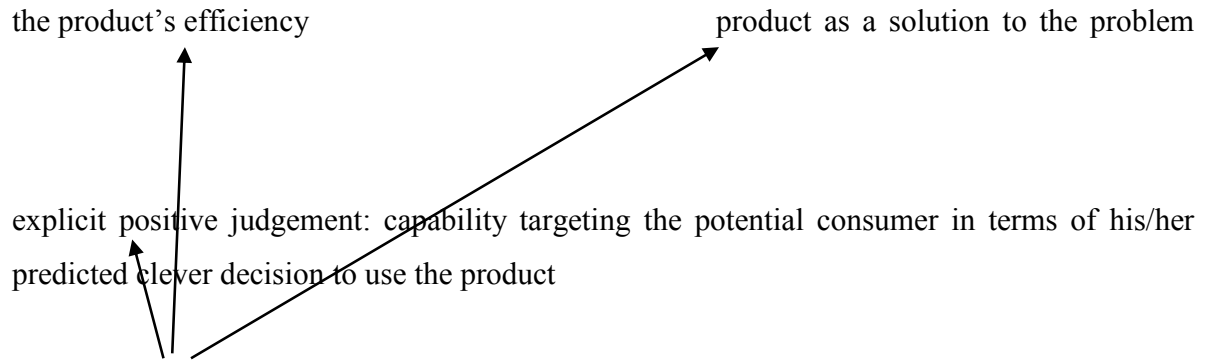

$[P]$ - a wiser way to stay in shape. Chillies improve metabolism, so Tracy thought she'd sussed it. She ate a dozen platefuls, but spontaneously combusted. New research shows that dairy calcium can be a great way to help your body metabolise fat more efficiently. So $[\mathrm{P}]$ has been made with more calcium on average than other probiotic drinks to help you manage your weight as a part of a balanced diet.

As shown above, capability often occurs in a pair with other attitudes. This is observed in particular in the ideational meanings of instances which have a scientific and innovative implication, such as formulations in (15) and scientifically in (16). Grammatically, such instances are realised 
primarily with things, epithets and adjuncts. There are three reasons why such instances may be treated as implicit judgement capability: first, the frequent occurrence of these instances in advertisements; second, the high value that is attributed to science in modern society; and third, the role of context in the interpretation of texts in systemic functional grammar. Additionally, the support for such coding can be found in the denotative meaning of the verb formulate, such as "to prepare a product by combining substances or chemicals in the right amounts" (MacMillan English Dictionary for Advanced Learners, 2007, 590). Since science is assumed to be closely associated with safety, and hence with trust, science, trust and safety are simultaneously indirectly introduced as positive values.

(15) $[P]$ now has a great new look with new packaging and improved formulations, plus a new invigorating variant called [P].

Double-coding of attitudes via formulations:

a) explicit positive appreciation targeting the product's innovative nature as part of a solution to the problem

b) implicit positive capability targeting the manufacturer's scientific approach to the product's development

(16) Only available from $[B],[P]$ is a range of high performance diagnostic products, scientifically developed for maximum results.

Double-coding of attitudes via scientifically:

a) explicit positive appreciation valuation targeting the product in terms of its scientific characteristics

b) implicit positive judgement capability targeting the manufacturer in terms of their scientific approach to the product's development

Frequently, specificity graders ${ }^{9}$ help evoke capability targeting the manufacturer. Examples include the names of specific technology, ingredients and substances that the manufacturer has cleverly and innovatively used to improve the product's efficiency, hence also increasing its value, as in (17) and (18).

(17) $[B]$ 's new innovative moisturizer with the benefits of Biodormin technology puts a pause on ageing signs

(18) Hibiscus, Agrimony and Brown Algae in new [P] lift, protect, reduce dark circles and puffiness for day-long beauty.

In (18), besides the capability value evoked by the manufacturer's wise decision to use specific (effective) ingredients in the product, each ingredient is also separately, indirectly and positively evaluated in terms of its characteristics, clearly expressed with examples conveying their benefits (lift, protect, reduce dark circles and puffiness). While positive appreciation towards each ingredient is evoked separately, the use of effective ingredients also indicates the product's efficiency, hence

In the analysis of attitude in academic writing, Hood $(2004,99)$ refined the dimension of graduation: focus by adding the categories of specificity, authenticity and fulfilment, whereby specificity refers to the degree of specificity of the boundaries of entities. Based on Hood's categorisation, names of products and brands, and kinds of technologies and ingredients used in products are considered as specificity markers 
evoking positive appreciation targeting it. Finally, the combination of these three ingredients evaluates the product positively as appreciation (composition) because the number of ingredients in the product is expected to enhance its quality.

The analysis further shows that positive capability, mostly targeting the manufacturer, is also indirectly identified:

- in commands which address the potential consumer's ability to solve the problem jointly with the manufacturer, hence emphasising the value of problem-solving,

(19) You don't sleep. So you worry about not sleeping. So you don't sleep. Let's break the circle.

- in propositions which give the potential consumer greater control and involvement in product production, hence emphasising individualism and creativity as values,

(20) In an instant, it hydrates the skin and adds definition-enhancing looks in a subtle and natural way. It's long lasting - from around six months to a year. But it's not permanent, which means you stay in control of the way you look. And that is the real beauty of [P].

(21) Design your own $[P]$ at...

- via quantifiers of extent and amount which point to the manufacturer's superiority on the basis of their high-quality work and success, hence presenting quality and success as positive values,

(22) Britain's number one private cosmetic surgery group.

- via engagement markers with which the manufacturer expresses facts, and reveals truths and reasons for using the product for the potential consumer's benefit,

(23) Does the weather at this time of year leave you feeling run down? It's a fact that winter is one of the most challenging times of year for your immune system. Drinking $[P]$ every day is scientifically proven to help support your immune system, part of your body's defences.

- via quantifiers of amount as statistical data to which the manufacturer has access (knowledge), foregrounding the value of trust and truth,

(24) 9 million women in the UK are affected by stress incontinence but medical research confirms $\mathbf{8 0 \%}$ of cases can be cured or improved if you undertake regular, effective pelvic floor exercise.

- via expectancy markers ${ }^{10}$ that clarify and justify the necessity for using the advertised product,

(25) Bad Breath: Why you're always the last to know. A simple question when someone you know or work with has bad breath, do you tell them? If you're like most people, the answer is probably 'No.' Which means that nobody is going to tell you when you have bad breath. So to be sure you don't, use [P] products.

- as the manufacturer's ability to find a solution to a problem,

10 'Expectancy' is a dialogic resource used by authors to present their propositions as justified or argued for, hence signalling a high level of commitment in the proposition (White 2003, 274). This encompasses the lexico-grammar of connectors and conjunctions which create, for example, meanings of insurance, purpose, means and reason (consequence). Under 'means', Martin and Rose (2003) include wordings such as thus and this means. 
(26) Weve figured out a way to make our [P] send themselves to sleep at night, in case you forget it.

- via categorical/factual statements that explain the causes of the problem (knowledge), and in this way justify the need for possessing the product, hence emphasising the value of trust,

(27) Theyre guaranteed to ban bad breath, because they actually get rid of something dentists call Volatile Sulphur Compounds, or VSCs. These are the end products of bacteria feeding off dead cell tissue and debris in the mouth.

- via technical terminology used by the manufacturer and their access to scientific information, hence emphasising the value of expertise

(28) Theyre guaranteed to ban bad breath, because they actually get rid of something dentists call Volatile Sulphur Compounds, or VSCs.

In many of the above cases, the manufacturer takes on the role of an expert and transmitter of knowledge on the basis of his/her access to professional/expert facts and knowledge. The establishment of an 'expert' social role, which obviously distances the manufacturer from the potential consumer socially (lacking expertise), may be regarded as persuasive on the basis of the trust that this expertise should trigger. However, social contact and power are occasionally mitigated through the manufacturer's explanation and clarification of important issues for the potential consumer's benefit, which then places the manufacturer into the social role of a helpful friend. In some cases, access to professional/expert information is shown explicitly with its attribution to the reliable external source, with the purpose of enhancing credibility, as in (29), whereby credibility is further enhanced with the positive appreciation new.

(29) Chillies improve metabolism, so Tracy thought she'd sussed it. She ate a dozen platefuls, but spontaneously combusted. New research shows that dairy calcium can be a great way to help your body metabolise fat more efficiently

Explicit negative capability features rarely and is encoded mostly as the potential consumer's lack of awareness of the problem, signalled with the modals can and may, coupled with a denial, as in (30), whereas implicit negative capability is encoded primarily in cases which assume a lack of specific information or knowledge on the part of the potential consumer. This is often seen in rhetorical questions and commands, which invite the potential consumer to consult an expert and make further inquiries, as in (31). In such cases, the values of knowledge and expertise are obviously foregrounded. In certain situations, however, external obstacles beyond one's control prevent the potential consumer's ability to act, hence releasing the potential consumer from responsibility, as in (32).

(30) You may not have realised it, but 70\% of your immune system is in your gut, which is where [P], with its unique culture L. casei Imunitass, goes to work.

(31) Ask your dentist about gum disease.

(32) You can't do much to prevent your children catching bugs when they mix with other kids all day long. 


\subsection{Explicit and Implicit Propriety}

Table 4 shows the pattern of judgement propriety in terms of its status and manifestation in advertisements.

TABLE 4. Status in explicit and implicit propriety attitudes.

\begin{tabular}{|l|c|c|c|}
\hline $\begin{array}{l}\text { explicit propriety } \\
\mathbf{n}=\mathbf{2 3}\end{array}$ & $\begin{array}{c}\text { implicit propriety } \\
\mathbf{n}=277\end{array}$ & \\
\hline positive & $20(85 \%)$ & positive & $249(90 \%)$ \\
\hline negative & $3(15 \%)$ & negative & $28(10 \%)$ \\
\hline
\end{tabular}

As shown in Table 4, positive propriety drastically prevails over negative propriety both in its explicit (85\%) and implicit form (90\%). Interestingly, implicit positive propriety is, of all propriety attitudes, expressed most frequently. On the basis of these results, it can be concluded that propriety is mainly expressed as a positive value both directly and indirectly. The results of the chi-squared test $\left(x^{2}\right)$ for the the status in explicit and implicit propriety attitudes show that there is a significant difference between the observed categories $\left(x^{2}=542.58 ; \mathrm{fe}=75 ; p=\right.$ 0.001(16.27), $\left.\mathrm{df}=3 ; p \leq x^{2}\right)$.

Explicit positive propriety is identified primarily in instances conveying the manufacturer's helpful, caring and fair approach towards the potential consumer, realised mainly as processes and attributes. The most typical representative is the lexical help coupled with the exclusive pronoun we/us, stressing the manufacturer's role of helpful friend. Help is offered for activities which the manufacturer assumes to be problematic for the potential consumer, who cannot deal with them successfully, targeting them with a negative judgement capability. The manufacturer's willingness to help signals that these activities are of importance, hence emphasised indirectly as important values, as in (33) and (34). By accepting help, the problem is solved and the potential consumer is able to make the most of their style and grow a whole grain family, which inscribes positive judgement capability on their part (see example 10). Additionally, in (33), the reformulation of the locution we use to help you into we use [in the product] to help you, facilitates identifying attitude of positive appreciation.

(33) Iron, steel, clay and silicone are just some of the ingredients we use to belp you make the most of yours. Now we've added something new to give your dishes a little extra fizz-colour.

(34) Wére belping you grow a whole grain family.

However, when the product is the doer of the action, only the attitude of appreciation targeting the product in terms of its efficiency and beneficial performance is coded, as there is no direct signal of the manufacturer's involvement (e.g., pronouns), as in (35):

(35) A herbal remedy traditionally used as an aid to slimming, taken as a part of a calorie controlled diet $[\underline{P]}$ can belp speed up your metabolism and make it easier for you to lose weight.

The potential consumer as the target of explicit positive propriety is also identified in the instances which directly convey the potential consumer's character as worthy of the product, realised as attributes in the relative clauses and mental processes, such as in the brand logo (36), and (37), and in instances which directly convey the manufacturer's sympathy for something or somebody, 
as in (38), which is considered a norm in society.

(36) Because you're worth it.

(37) You deserve the best for your kitchen.

(38) So we were particularly pleased to win the RSPCA's first Alternative Award for Food retailers, and be named 'Compassionate Supermarket of the year' by Compassion in World Farming.

Implicit positive propriety features extremely frequently. Most of the implicit positive propriety is evoked in instances which are often coupled with the purpose marker of proclaiming ${ }^{11}$ engagement to (e.g., designed to, developed to, created to), signalling the manufacturer's concern and care for the potential consumer by developing a product that is aimed at meeting their individual needs (e.g., pronoun your), as in (39). In (39), the care and concern are further indicated in the positive evaluations targeting the product (belp, protect) in the vicinity of the aforementioned instances.

(39) $[P]$ is designed to help protect your skin's inner structure and outer health.

The manufacturer's intention to meet the potential consumer's individual needs can be further observed in a number of features: use of the specificity marker for, the listing of kinds of available products (41), and lexical amount quantifiers realised as things in nominal groups conveying the number of available products (e.g., range, collection).

(40) $[B]$ offers something for everyone.

(41) Among the range of over 450 products, you will find products that are organic, vegetarian, hypoallergic, kosher, varied dosages and highly absorbable forms.

Moreover, the manufacturer displays their caring attitude in a number of ways: by granting the potential consumer second chances and compensating them; by using the best and most natural ingredients; by improving the product and being environmentally aware and health-conscious, as seen in (42-47). The manufacturer, as the target of positive propriety, is often overtly revealed through the pronoun we. Moreover, the beneficial target of the manufacturer's caring attitudes is often directly exposed through the pronoun you/your. The identification of propriety in these examples is not always based only on semantic meanings of instances (eco-friendly, finest) but also on the linguistic elements in the proposition, such as denials (free), quantifiers (second, added) and comparisons (finest). Additionally, since allowing someone another opportunity and refunding money are often-ignored social norms (in a money-driven and individualistic society), both are emphasised.

(42) We don't like to boast but we're the only company making butter from free-range milk.

(43) Imagine erasing visible past damage to create a more even looking skin tone. In fact, [B] guiding dermatologist Dr [B] says: 'When skin is more even-toned, you look younger'. So, here's your second chance.

(44) You have to be the best in your field if you want that honour. That's because we scour the globe for the finest ingredients.

11 Elements of logico-semantic relations, such as cause, means, purpose and condition, are some of the resources of the proclaim category in the engagement system in the appraisal model that indicate the authorial interference in the text. 
(45) Now we've added something new to give your dishes a little extra fizz-colour.

(46) Say goodbye to Cardboard jeans or get your money back.

(47) In fact, we're one of the top three most eco-friendly petrol cars there is according to the Government's new Low Carbon Vehicle Partnership.

Negative propriety is frequently evoked next to positive propriety via counter-expectancy markers (e.g., even, yet, still). The markers evoke positive propriety targeting the manufacturer's unexpected generosity, and in this way, imply that other manufacturers lack this trait, as shown in (48).

(48) [P] is a whole new way to floss. It gently vibrates. So flossing feels really good and is a lot easier. It even comes with pick and flosser refills. The new buzz in flossing.

\section{Conclusion}

The results show that the categories of capability and propriety, two of the five attitudinal categories in the Martin and White appraisal model (2005), greatly prevail over the categories of normality, tenacity and veracity. In terms of status, both capability and propriety occur primarily with a positive status, targeting mainly the manufacturer in terms of: their knowledge and skills, and scientific approaches they bring to the product's development; their offers of help in solving and dealing with problems; their generosity, compassion, eco-awareness, and concern for fair treatment; their understanding nature and willingness to find an individual approach to best meet the potential consumer's needs. Their social roles as generous and helpful friends toward the potential consumer are also strongly emphasised. On the other hand, positive capability and propriety targeting the potential consumer are reflected in: the lexis and propositions which directly or indirectly convey the joint resolution of problems with the manufacturer; increased control over the product by the potential consumer; the potential consumer's creativity and involvement in the product's design; descriptions of the potential consumer as worthy of the product on the basis of their hard work and positive character; and encouragement of the potential consumer's ability to solve their problems. However, in contrast to the manufacturer, the potential consumer is occasionally targeted with negative capability and propriety in terms of lacking knowledge and important information, implied via factual statements and rhetorical questions, which points to the problem which the potential consumer (presumably) has. Furthermore, I hope to have demonstrated that the identification of propriety and capability within creative and brief advertising texts is often challenging, and requires the participation of the context, which encompasses the participants' background and shared knowledge, assumptions, and presuppositions, as well as implications, co-text, and possible interpretations of meanings. In this way, the article has attempted to support the claims regarding the importance of context in the creation and interpretation of meanings, and hence in the identification of appraisals. Even though the judgement attitudes of capability and propriety are only a small part of the entire appraisal model, the article attempted to demonstrate the important social role appraisals play in advertisements by directly and indirectly revealing the value system, social roles and relationships of the participants. Furthermore, the analysis of textual sections of advertisements has lain the groundwork for a detailed analysis of visuals and their interplay. 


\section{References}

Beangstrom, Tracy, and Ralph Adendorff. 2013. "An APPRAISAL analysis of the language of real estate advertisements." Southern African Linguistics \& Applied Language Studies 31(3): 32547. doi:10.2989/16073614.2013.837608.

Bednarek, Monika. 2006. Evaluation in Media Discourse: Analysis of a Newspaper Corpus. London, New York: Continuum.

—. 2009. "Language patterns and Attitude". Functions of Language 16(2): 165-92. doi:10.1075/fol.16.2.01bed.

—. 2014. "An astonishing season of destiny! Evaluation in blurbs used for advertising TV series." In Evaluation in Context, edited by Geoff Thompson and Laura Alba-Juez, 197-220. Amsterdam and Philadelphia: John Benjamins Publishing Company.

Bowcher, Wendy L., ed. 2012. Multimodal Texts from Around the World: Cultural and Linguistic Insights. Basingstoke, Hampshire: Palgrave Macmillan.

Brown, Penelope, and Stephen C. Levinson. 1987. Politeness: Some universals in language usage. Cambridge: Cambridge University Press.

Brown, H. Douglas. 2001. Teaching by Principles: An Interactive Approach to Language Pedagogy. San Francisco State University: Longman.

Butt, David, Rhondda Fahey, Susan Feez, Sue Spinks, and Colin Yallop. 2000. Using Functional Grammar. An Explorer's Guide. National Centre for English language Teaching and Research: Macquarie University.

Caldas-Coulthard, Carmen Rosa. 1996. "Women who pay for sex. And enjoy it: transgression versus morality in women's magazines." In Texts and Practices. Readings in Critical Discourse Analysis, edited by Carmen Rosa Caldas-Coulthard and Malcolm Coulthard, 255-70. London and New York: Routledge.

Carter, Ronald. 2004. Language and Creativity. London: Routledge.

Channel, Joanna. 1999. "Corpus-based analysis of evaluative lexis." In Evaluation in Text. Authorial Stance and the Construction of Discourse, edited by Susan Hunston and Geoff Thompson, 38-55. Oxford: Oxford University Press.

Don, Alexanne. C. 2007. "A Framework for the investigation of interactive norms and the construction of textual identity in written discourse communities: The case of an email list." PhD diss. University of Birmingham. Accessed May 10, 2015 http://www.grammatics.com/appraisal/lexi_con/lexis-text/thesis/ donacphd.html

—. 2016. "It is hard to mesh all this': Invoking attitude, persona and argument organisation." Functional Linguistics 3(9). doi:10.1186/s40554-016-0033-1.

Eco, Umberto.1979. The role of the Reader: Explorations in the Semiotics of Texts. Bloomington: Indiana University Press.

Fuoli, Matteo. 2018, forthcoming. "A step-wise method for annotating APPRAISAL." Functions of Language 25(1). Accessed October 20, 2016 http://portal.research.lu.se/portal/files/8642529/FUOLI_A_stepwise_ method_for_annotating_appraisal_MANUSCRIPT.pdf

Halliday, Michael A.K., and Christian M.I. Mathiessen. 2004. An Introduction to Functional Grammar. London: Hodder Arnold.

Hayakawa, Samuel Ichiye. [1939]1972. Language in Thought and Action. New York: Harcourt Brace Jovanovich.

Hoey, Michael. 1994. "Signalling in discourse: a functional analysis of a common discourse pattern in written and spoken English." In Advances in Written Text Analysis, edited by Malcolm Coulthard, 26-45. London and New York: Routledge. 
—. 2001. Textual Interaction: an Introduction to Written Discourse Analysis. London and New York: Routledge.

Hommerberg, Charlotte, and Alexanne Don. 2015. "Appraisal and the language of wine appreciation: A critical discussion of the potential of the Appraisal framework as a tool to analyse specialised genres." Functions of Language 22(2): 161-91. doi:10.1075/fol.22.2.01 hom.

Hood, Susan. 2004. “Appraising Research: Taking a Stance in Ccademic Writing.” PhD diss. University of Technology, Sydney. Accessed April 12, 2010 http://www.grammatics.com/appraisal/suehoodphd/hood_ title_page.pdf

Hunston, Susan. 1999. "Evaluation and the Planes of Discourse: Status and Value in Persuasive texts." In Evaluation in Text: Authorial Stance and the Construction of Discourse, edited by Susan Hunston and Geoff Thompson, 176-207.

Hunston, Susan, and Geoff Thompson, eds. 1999. Evaluation in Text: Authorial Stance and the Construction of Discourse. Oxford: Oxford University Press.

Iedema, Rick, Susan Feez, and Peter R.R. White. 1994. Media Literacy. Disadvantaged Schools Program. NSW Department of School Education.

Isaac, Anne. 2012. "Modelling voice as Appraisal and Involvement resources: The portrayal of textual identities and interpersonal relationships in the written stylistic analyses of non-native speaker, international undergraduates.” PhD diss. University of Canberra. Accessed June 15, 2015 http://www.canberra.edu.au/ researchrepository/file/62aea368-2653-479d-a733-ff2c3a4c690c/1/full_text.pdf

Jacobson, Roman. 1960. "Closing Statement: Linguistics and Poetics." In Style in Language, edited by Thomas A. Sebeok, 350-77. Cambridge, MA: MIT Press.

Jones, T.M. 2001. “The Battle for Your Mind.The Socialist Party of Great Britain.” Accessed February 2, 2016 http://www.worldsocialism.org/spgb/socialist-standard/2000s/2001/no-1159-february-2001/battle-yourmind

Kress, Gunther. 1988. Communication and Culture: An Introduction. Kensington: New South Wales University Press.

Kress, Gunther, and Robert Hodge. 1979. Language as Ideology. London: Routledge and Kegan Paul.

Kress, Gunther, and Theo van Leeuwen. 1996. Reading Images: The Grammar of Visual Design. London: Routledge.

-.1999. "Representation and Interaction: Designing the Position of the Viewer." In The Discourse Reader, edited by Adam Jaworski and Nikolas Coupland, 377-414. London and New York: Routledge.

-.2006. Reading images: The grammar of visual design. London: Routledge.

Labov, William. 1972. The Transformation of Experience in Narrative Syntax. Language in the Inner City. Philadelphia: Pennsylvania University Press.

Lamb David A. 2014. Text, Context and the Johannine Community: A Sociolinguistic Analysis of the Johannine Writings. London and New York: Bloomsbury T\&T Clark.

Leckie-Tarry, Helen. 1995. Language and Context: A functional linguistic theory of register, edited by David Birch. London and New York: Pinter.

Lemke, Jay L. 1998. "Resources of Attitudinal Meaning: Evaluative Orientations in Text Semantics." Functions of Language 5(1): 33-56. doi:10.1075/fol.5.1.03lem.

Macken-Horarik, Mary. 2003. “APPRAISAL and the special instructiveness of narrative." Text 23(2): 285312. doi: 10.1515/text.2003.012,

Macken-Horarik, Mary, and Anne Isaac. 2014. “Appraising Appraisal”. In Evaluation in context, edited by Geoff Thompson and Laura Alba-Juez, 67-92. Amsterdam: Benjamins. 
Martin, James R. 1992. English Text: System and Structure. Philadelphia/Amsterdam: John Benjamins Publishing Company.

Martin, James R., and Peter R. R. White. 2005. The Language of Evaluation. Appraisal in English. Hampshire and New York: Macmillan.

Martin, James R., and David Rose. 2003. Working with Discourse: Meaning beyond the Clause. London and New York: Continuum.

MacMillan English Dictionary for Advanced Learners. 2007. Oxford: MacMillan

O’Donnell, Michael. 2008. "The UAM Corpus Tool: Software for corpus annotation and exploration.” Proceedings of the XXVI Congreso de AESLA, Almeria, Spain, 3-5 April 2008. Accessed October 12, 2016 http://www.uam.es/proyectosinv/woslac/DOCUMENTS/Presentations\%20and\%20articles/ ODonnellAESLA08.pdf

O'Halloran, Kay. 2005. Mathematical Discourse: Language, Symbolism and Visual Images. London: Continuum.

Page, Ruth E. 2003. "An Analysis of APPRAISAL in childbirth narratives with special consideration of gender and storytelling style." Text 23(2): 211-37. doi:10.1515/text.2003.009.

Painter, Claire. 2003. "Developing attitude: An ontogenetic perspective on APPRAISAL." Text 23(2): 183209. doi:10.1515/text.2003.008.

Pollay, Richard W., and Katherine Gallagher. 1990. "Advertising and cultural values: Reflection in the distorted mirror". International Journal of Advertising 9(4): 359-72. doi:10.1080/02650487.1990.11107158.

Poynton, Cate. 1985[1989]. Language and Gender: Making the Difference. Victoria: Deakin University Press.

Richards, Ivor Armstrong. 1926. “The two uses of language.” In Principles of Literary Criticism, edited by Ivor Armstrong Richards, 261-71. London: Routledge and Kegan Paul.

Rimmon-Kennan, Schlomith. 1983. Narrative Fiction: Contemporary Poetics. London: Methuen.

Saint-Martin, Fernande.1990. Semiotics of Visual Language. Bloomington, IN: Indiana University Press.

Selden, Raman and Peter Widdowson. 1993. A Reader's Guide to Contemporary Literary Theory. 3rd ed. Lexington: The University Press of Kentucky.

Stern, Barbara B. 1994. "A Revised Communication Model for Advertising: Multiple Dimensions of the Source, the Message, and the Recipient." Journal of Advertising, 23(2): 5-15. doi: 10.1080/00913367.1994.10673438.

Stoian, Claudia Elena. 2015. Meaning in Images: Complexity and Variation across Cultures. In Meaning Making in Text: Multimodal and Multilingual Functional Perspectives, edited by Sonja Starc, Carys Jones, and Arianna Maiorani, Basingstoke, UK, Palgrave Macmillan, 152-69.

Tan, Sabine. 2010. "Modelling engagement in a web-based advertising campaign." Visual Communication 9(1): 91-115. doi:10.1177/1470357209352949.

Thibault, Paul John. 2000. "The Multimodal Transcription of a Television Advertisement: Theory and Practice." In Multimodality and Multimediality in the Distance Learning Age, edited by Anthony P. Baldry and Campo Basso: Lampo, 311-84.

Thompson, Geoff. 2014. "AFFECT and emotion, target-value mismatches, and Russian dolls: Refining the APPRAISAL model.” In Evaluation in Context, edited by Geoff Thompson and Laura Alba-Juez, 47-66. Amsterdam and Philadelphia: John Benjamins Publishing Company.

Vološinov, Valentin N. 1973. Marxism and the Philosophy of Language. Cambridge, MA: Harvard University Press. 
Wales, Katie. 2014. A Dictionary of Stylistics. 3rd ed. London and New York: Routledge.

White, Peter R.R. 1998. Telling Media Tales: The News Story as Rhetoric. PhD diss., University of Sydney. Accessed March 24, 2016 http://www.grammatics.com/appraisal/whiteprr/whiteprr_phd.html

—. 2001. "Appraisal: An Overview. Introduction: the origins of the Appraisal framework." Accessed May 25, 2014. http://www.grammatics.com/appraisal/appraisaloutline/framed/frame.htm.

- 2003. "Beyond modality and hedging: A dialogic view of the language of intersubjective stance." Text 23(2): 259-84. doi:10.1515/text.2003.011.

\section{Sources}

Marie Claire, October, 2005, 115, 113, 179, 203; August, 2005, 263, 348, 54, 281, 262, 263; October, 2004, 225, 407, 412; April, 2007, 75, 178; July, 2007, 89, 262, 115, 275, 25, 158, 73, 118, 217, 291;

December, 2004, 301, 114; April, 2008, 15

Red, November, 2006, 275, 74, 127, 78, 57; November, 2006, 83

Eve, April, 2007, 124, 142; October, 2004, 48

Grazia, May, 2007, 124; November, 2008, 53

She, January, 2005, 85, 56, 157, 86

Vanity Fair, October, 2006, 115

New Woman, October, 2004, 215, 143; July, 2005, 56 
